\title{
Chronically HIV-1 Infected Patients Exhibit Low Frequencies of CD25+ Regulatory T Cells
}

\author{
Cesar Mauricio Rueda Rios ${ }^{*}$, Paula Andrea Velilla and Maria Teresa Rugeles
}

\author{
Grupo Inmunovirologia, Universidad de Antioquia, Medellín, Antioquia, Colombia
}

\begin{abstract}
The characterization of regulatory $\mathrm{T}$ cells (Treg) during HIV infection has become of particular interest considering their potential role in the pathogenesis of the acquired immunodeficiency syndrome. Different reports on Tregs in HIV-infected patients vary greatly, depending on the state of disease progression, anatomical compartment, and the phenotypic markers used to define this cell subpopulation. To determine the frequency of Tregs we included paired samples from peripheral blood and rectal biopsies from controls and chronic HIV patients with or without detectable viral load. Tregs were determined by flow cytometry using three different protocols: $\mathrm{CD} 4^{+} \mathrm{Foxp}^{+}$; $\mathrm{CD} 4^{+}$Foxp $3^{+} \mathrm{CD} 127^{\mathrm{Low} /-}$, and $\mathrm{CD} 4^{+} \mathrm{CD} 25^{+} \mathrm{CD} 127^{\text {Low/- }}$. In addition, and with the purpose to compare the different protocols we also characterized Tregs in peripheral blood of HIV negative individuals with influenza like symptoms. Here, we report that Treg characterization in HIV-infected patients as $\mathrm{CD} 4{ }^{+} \mathrm{Foxp} 3^{+}$and $\mathrm{CD} 4{ }^{+} \mathrm{Foxp} 3^{+} \mathrm{CD} 127^{\text {Low/- }}$ cells was similar, indicating that both protocols represent a suitable method to determine the frequency of Tregs in peripheral blood mononuclear cells (PBMC) and gut associated lymphoid tissue (GALT). In contrast, in HIV but not in flu-like patients, detection of Tregs as $\mathrm{CD} 4{ }^{+} \mathrm{CD} 25^{+} \mathrm{CD} 127^{\text {Low/- }}$ cells resulted in a significantly lower percentage of these cells. In both, HIV patients and controls the frequency of Treg was significantly higher in GALT compared to PBMC. The frequency of Tregs in PBMC and GALT using $\mathrm{CD}^{+}{ }^{+} \mathrm{Foxp}^{+}$and $\mathrm{CD} 4^{+} \mathrm{Foxp}^{+} \mathrm{CD} 127^{\mathrm{Low} /-}$ was higher in HIV patients than in controls. Similarly, the frequency of Treg using any protocol was higher in flu-like patients compared to controls. The results suggest that relying on the expression of CD25 could be unsuitable to characterize Tregs in PBMC and GALT samples from a chronic infection such as HIV.
\end{abstract}

Keywords: Regulatory T cell, human immunodeficiency virus, CD25, phenotype.

\section{INTRODUCTION}

Regulatory $\mathrm{T}$ cells (Treg) play a major role in maintaining self-tolerance and limiting antiviral responses during chronic infections. Treg is a subpopulation of $\mathrm{CD}^{+} \mathrm{T}$ cells characterized by their potent capacity to reduce the activation and expansion of conventional $\mathrm{T}$ cells (Tcon) $[1$, 2]. Considering that immune activation is a hallmark of human immunodeficiency virus type-1 (HIV) infection, a considerable number of studies have explored the role of Treg in different cohorts of patients, reporting contradictory data. In peripheral blood, several studies have reported a reduction in the percentage of Treg in HIV patients, independent of viral load, compared to controls [3,4]; in contrast, other reports indicate either an increase in this $\mathrm{T}$ cell subpopulation [5-8] or no change [9,10]. Although several factors, including the stage of infection and the heterogeneity of the HIV populations studied can account for these differences, technical considerations in the phenotypic characterization of these cells cannot be ruled out. The first concern is that most of the original reports indicating frequency and absolute counts of Treg in HIV patients were based on the assumption that a high level of CD25 expression is a reliable marker for human Treg [11, 12]. There is no doubt that the $\mathrm{CD} 4^{+} \mathrm{CD} 25^{\text {hi }} \mathrm{T}$ cell subset has the

*Address correspondence to this author at the School of Medicine, University of Antioquia, Calle 62 \# 52-59, Of. 532, Sede de Investigación Universitaria, Medellín, Colombia; Tel: 57-4-2-6482; Fax: 57-4-219-6481;

E-mail: cesarued@hotmail.com greatest regulatory potential [13]; however, there is also evidence that activated conventional cells have upregulated the CD25 molecule [14].

A better characterization was achieved by determining the expression of Foxp3, the best marker so far identified to characterize this cell subpopulation; however, this molecule is also transiently expressed in a small percentage of activated $\mathrm{CD}^{+}$Tcon, and it is not convenient to purify the cells because its detection implies permeabilization [15]. Later, in 2006 the absence or low expression of the alpha chain of the IL-7 receptor, the CD127 molecule, along with the expression of the transcription factor Foxp3, were considered the most specific markers of this cell population $[13,16]$.

Although flow cytometry is an efficient tool to determine the phenotype and functional activity of Treg [13, 16, 17], there is still some controversy regarding the molecules used for their characterization, particularly in the context of chronic infections [18]. In addition, most of the immune alterations occurring during HIV infection have been well documented in peripheral blood. However this virus has a greater impact in lymphoid organs, particularly in GALT, the main site of HIV replication [19], where little is known regarding Treg phenotype. In this study we compared three different protocols to characterize Tregs. We included samples from peripheral blood and gut associated lymphoid tissue (GALT) of healthy controls and two groups of chronically HIV infected patients: patients with viral load and patients with undetectable viral load. Here, we explore if 
type of tissue sample or the virus influence the Treg phenotypic alteration. In addition, and with the purpose of determining whether changes in Treg are specific of HIV infection or associated to any inflammatory/activation process due to any infection, we also characterized Tregs in peripheral blood of HIV negative individuals with influenza like symptoms. The results suggest that relying on the expression of CD25 is unsuitable to characterize Tregs in peripheral blood mononuclear cells (PBMC) and GALT samples from HIV patients.

\section{MATERIALS AND METHODS}

\section{Subjects}

Four groups of subjects, from Medellin, Colombia, were included in the study: HIV negative healthy controls ( $\mathrm{HC}$, $\mathrm{n}=10$ ); HIV negative individuals with acute flu-like symptoms (Flu, $n=9$ ); chronic HIV-1-infected patients with undetectable viral load (HIV-U, $\mathrm{n}=13$ ) and HIV-1-infected patients with viral load (HIV-VL, $\mathrm{n}=19$ ). Flu-like patients had an average of five days with symptoms such as fever, malaise, headache, sore throat, nasal congestion and weakness; all patients had rapid spontaneous resolution of the disease in absence of treatment. To rule out bacterial infection, para-clinical examinations were carried-out. Healthy controls and flu-like patients were screened to rule out HIV infection by electrochemiluminescence (HIV combi PT, Roche Diagnostics; Mannheim, Germany).

HIV patients, with at least two years of confirmed infection, classified in the $\mathrm{B}$ clinical category, according to the CDC criteria were included. The demographic and clinical characteristics of these individuals are shown in Table 1. Absolute number and percentage of $\mathrm{CD}^{+} \mathrm{T}$-cell were calculated in whole blood samples. Plasma HIV-1 RNA levels were assessed by RT-PCRq (COBAS AmpliPrep/ COBAS TaqMan, Roche Molecular).

\section{Isolation of Cells from Peripheral Blood and GALT}

PBMC were obtained from $10 \mathrm{ml}$ of heparin venous blood samples by centrifugation on Histopaque (SigmaAldrich, St Louis, MO, USA) for $30 \mathrm{~min}$ at $400 \mathrm{x} \mathrm{g}$. Mucosal samples were processed as described by the Shacklett protocol [20] with minor modifications. Rectal tissue was obtained by rectosigmoidoscopy from the rectum at $10 \mathrm{~cm}$ from the anal verge. A flexible sigmoidoscope with a single endoscopy biopsy forcep FB-24K-1 (Olimpus America Corp, Melville, NY, USA) was used. Samples were processed by digestion using collagenase type II from Clostridium histolyticum (Sigma) at $0.5 \mathrm{mg} / \mathrm{ml}$ diluted in RPMI 1640 and 7.5\% FCS (fetal calf serum) (penicillin 100 $\mathrm{U} / \mathrm{ml}$, streptomycin $100 \mathrm{~g} / \mathrm{ml}$, amphotericine B $0.25 \mathrm{~g} / \mathrm{ml}$ ) (Gibco-BRL; Grand Island, NY, USA), during $30 \mathrm{~min}$ at $37^{\circ} \mathrm{C}$ while shaking. After collagenase digestion, biopsy fragments were further disrupted by repeated passage through a $30 \mathrm{ml}$ syringe with a blunt ended 16 gauge needle (Stem Cell Technologies, Vancouver, BC). Rectal cells (RC) were isolated by passage through a nylon strainer of $70 \mu \mathrm{M}$ (Falcon, Lincoln Park, NJ, USA). PBMC and RC were washed with Dulbeco's phosphate buffered saline (DPBS) (Sigma-Aldrich; St Louis, MO, USA) to remove excess histopaque and collagenase, respectively.

\section{Flow Cytometry Analysis of PBMC and RC}

PBMC and RC were treated with $20 \mathrm{ug} / \mathrm{ml}$ of human IgG (Sigma-Aldrich; St Louis, MO, USA) to block Fc receptors, and stained on the surface with anti-CD4-ECD (clone SFCI12T4D11) (Beckman Coulter Fullerton, CA, USA) anti-CD3-PE-CY7 (clone UCHT1), anti-CD25-PE-CY5 (clone BC96) and anti-CD127-PE (IL-7 R $\alpha$, clone RDR5) (eBioscience, San Diego, CA, USA) for $30 \mathrm{~min}$ at $4^{\circ} \mathrm{C}$. The cells were washed with DPBS, then fixed/permeabilized (Foxp3 staining buffer kit, e-Bioscience) and stained intracellularly using monoclonal antibodies against antiFoxp3-FITC (clone PCH101), for $30 \mathrm{~min}$ at $4^{\circ} \mathrm{C}$. At least 100,000 events were acquired for each sample in the lymphocyte region, using the flow cytometry FC500 (Beckman Coulter Fullerton, CA), and analyzed using the Kaluza Software (Beckman Coulter Fullerton, CA). T cells were gated first based on forward- and side-scatter properties, then as $\mathrm{CD} 3^{+} \mathrm{CD} 4^{+}$cells (Fig. 1A). The strategy followed to detect Treg was previously reported by Presicce et al., 2010 [21] and Seddiki et al., 2006a [16] protocols. Briefly, to define the limit of the positive gate, a negative biological population $\left(\mathrm{CD} 3^{-} \mathrm{CD} 4^{-}\right.$or $\left.\mathrm{CD} 3^{+} \mathrm{CD} 4^{-}\right)$, previously known for not expressing the marker of interest, was used [21]; the Mean fluorescence intensity (MFI) was analyzed within the positive population.

\section{Statistical Analysis}

Statistical analyses were performed using GraphPad Prism 5 (San Diego, CA, USA). The data are shown as median (25th percentile-75th percentile). Comparisons of medians among groups were performed by the U-MannWhitney test or the Kruskal Wallis test with Dunn's multiple comparisons post-test. Intragroup comparisons were made

Table 1. Characteristics of Healthy Controls, Flu-Like, HIV with and Undetectable Viral Load

\begin{tabular}{|c|c|c|c|c|}
\hline & Healthy Controls $(n=10)$ & Flu-Like $(n=9)$ & HIV Undetectable Viral Load $(n=13)$ & HIV With Viral Load $(n=19)$ \\
\hline Age (years) ${ }^{1}$ & $46(13)$ & $30(7)$ & $42(9)$ & $38(12)$ \\
\hline$\%$ Male/Female & $50 / 50$ & $45 / 55$ & $85 / 15$ & $95 / 5$ \\
\hline$\% \mathrm{CD}^{+} \mathrm{T}$ cell $^{2}$ & $39(32-46)$ & $34(32-41)$ & $16^{* * \varphi}(12-31)$ & $18^{* * * \varphi}(10-24)$ \\
\hline$\% \mathrm{CD}^{+} \mathrm{T}_{\text {cell }}^{2}$ & $20(16-23)$ & $32^{*}(22-34)$ & $45^{* * * \varphi}(34-56)$ & $46^{* * * \varphi}(42-57)$ \\
\hline HIV Viral load (copies $/ \mathrm{ml})^{2}$ & N/A & $\mathrm{N} / \mathrm{A}$ & $<40(40-40)$ & $12500^{\wedge}(230-50190)$ \\
\hline
\end{tabular}

${ }^{1}$ Results are expressed as mean (SE); ${ }^{2}$ Results are expressed as median (25th-75th percentiles). Groups were compared by the Kruskal-Wallis test and the Dunn's multiple comparison post-test. Significant differences are indicated by $* * \mathrm{p}<0.01, * * * \mathrm{p}<0.001$ compared to helthy control group and $\varphi_{\mathrm{p}}<0.01$ with the flu-like group. Comparation by $\mathrm{U}$ Mann Whitney test between controls and flu groups are indicated by ${ }^{*} \mathrm{p}<0.01$ and between both groups of HIV-1 positive patients by ${ }^{\wedge} \mathrm{p}<0.001$. N/A: not applicable. 


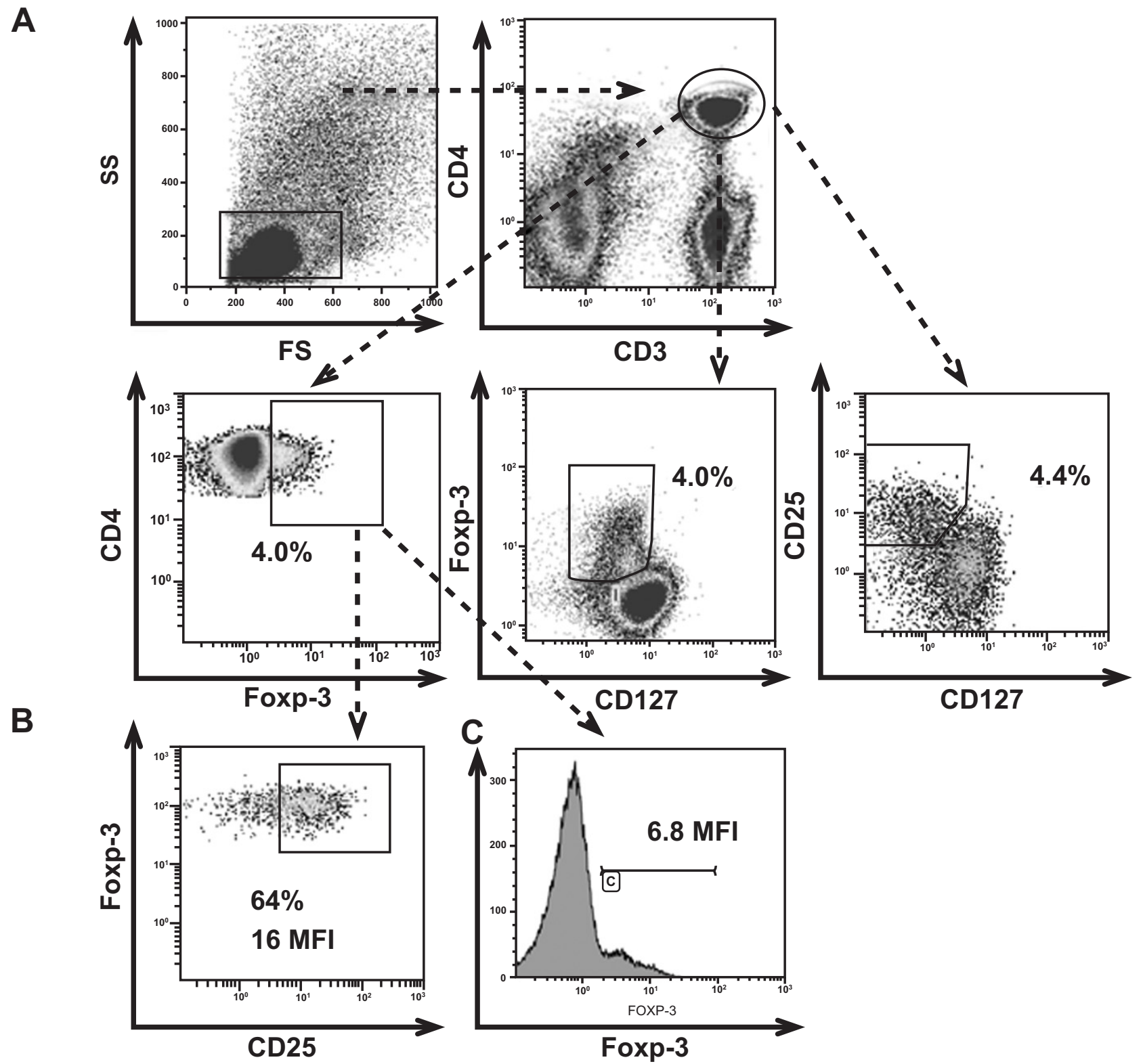

Fig. (1). Chacterization of Treg phenotype. Staining of Treg was made with conjugated monoclonal anti-CD3-PE-CY7, anti-CD4-ECD, anti-CD25-PE-CY5, anti-CD127-PE and anti-Foxp3-FITC antibodies. A) Scatter blot from one representative figure of flow cytometry data shows the frequency of Treg in PBMC in an individual from a healthy control group. Three different ways of defyning Treg were analyzed: $\mathrm{CD}^{+} \mathrm{Foxp}^{+}$(right panel), $\mathrm{CD} 4^{+} \mathrm{Foxp}^{+} \mathrm{CD} 127^{\text {Low/- }}$ (middle panel) and $\mathrm{CD} 4^{+} \mathrm{CD} 25^{+} \mathrm{CD} 127^{\text {Low/- }}$ (left panel). In the Foxp $3^{+}$gate the following analysis were done. B) percentage and MFI of CD25 molecule; and C) MFI of Foxp3.

with Friedmann test. Correlations were made with spearman test and $p$ values less than 0.05 were considered to be statistically significant.

\section{RESULTS}

\section{Patient Characteristics}

As shown in Table $\mathbf{1}$, the percentage of $\mathrm{CD}^{+} \mathrm{T}$ cells were reduced in both groups of HIV patients (with detectable and undetectable viral load) compared to controls (HC vs HIV-U; p<0.01) (HC vs HIV-VL; $\mathrm{p}<0.001)$ and flu-like (both $\mathrm{p}<0.01$ ). Controls, flu-like, HIV-U and HIV-VL exhibit $\mathrm{CD}^{+} \mathrm{T}$ cell counts of 905 cells $/ \mathrm{mm}^{3}(692-1093$ cells $\left./ \mathrm{mm}^{3}\right), \quad 815$ cells $/ \mathrm{mm}^{3} \quad\left(645-923\right.$ cells $\left./ \mathrm{mm}^{3}\right), \quad 439$ cells $/ \mathrm{mm}^{3}\left(301-986\right.$ cells $\left./ \mathrm{mm}^{3}\right)$ and 426 cells $/ \mathrm{mm}^{3}(287-707$ cells $\left./ \mathrm{mm}^{3}\right)$, respectively. The $\mathrm{CD}^{+} \mathrm{T}$ cell counts were strikingly low in the HIV-VL group compared with controls $(\mathrm{p}<0.05)$. As expected, the percentages of $\mathrm{CD}^{+} \mathrm{T}$-cells were higher in all individuals with viral infection (HIV and Flu) compared to controls, with the highest values found in both HIV groups (Table 1). All the patients with undetectable viral load had been on highly active antiretroviral therapy (HAART) for a median of 8 (3-12) years. 
Low Frequency of $\mathrm{CD}^{+} \mathrm{CD}^{+} 5^{+} \mathrm{CD} 127^{\text {Low/- }}$ Tregs Detected During Chronic HIV Infection in Peripheral Blood and Gastrointestinal Tissue

To characterize the Treg subset during HIV infection, we analyzed the frequency of Treg using the following protocols: i) $\mathrm{CD}^{+} \mathrm{Foxp}^{+}$; ii) $\mathrm{CD} 4^{+} \mathrm{Foxp} 3^{+} \mathrm{CD} 127^{\text {Low/ }}$; and iii) $\mathrm{CD}^{+} \mathrm{CD} 25^{+} \mathrm{CD} 127^{\mathrm{Low} /-}$ (Fig. 1A) as reported by Seddiki et al., [16]. As shown in Fig. (2A), the percentage of Treg in PBMC from healthy donors (upper panel) and flu-like patients was similar intra-group, regardless of the protocol used. In contrast, the percentage of Treg from HIV samples varied depending of the protocol. In the HIV-U group the frequency was similar, $7 \%(6-10 \%)$ and $7 \%(5-8 \%)$ when the Treg were defined as $\mathrm{CD}^{+} \mathrm{Foxp}^{+}$, and $\mathrm{CD}^{+} \mathrm{Foxp}^{+}$ $\mathrm{CD} 127^{\mathrm{Low} /}$ respectively; however, the frequency was significantly lower, only $4 \%$ (4-6\%), when these cells were defined as $\mathrm{CD} 4^{+} \mathrm{CD} 25^{+} \mathrm{CD} 127^{\text {Low/- }}$ (Fig. 2A; p $<0.05$ compared to $\left.\mathrm{CD} 4^{+} \mathrm{Foxp}^{+}{ }^{+}\right)$. Similarly, in the HIV-VL group the frequency of Treg was 7\% (6-10\%) and 6\% (5-8\%) when the Treg were defined as $\mathrm{CD}^{+} \mathrm{Foxp}^{+}$, and $\mathrm{CD} 4^{+} \mathrm{Foxp} 3^{+} \mathrm{CD} 127^{\text {Low/- }}$ respectively; however, the frequency was lower with the $\mathrm{CD} 4^{+} \mathrm{CD} 25^{+} \mathrm{CD} 127^{\text {Low/- }}$ protocol compared to $\mathrm{CD}^{+} \mathrm{Foxp}^{+}{ }^{+}(5 \%$ (4-8\%) vs $7 \%$ (6$10 \%$ ); $<<0.001$ ) (Fig. 2A).

Interestingly, and probably due to an inflammatory process in both, chronic (HIV: using $\mathrm{CD}^{+} \mathrm{Foxp}^{+}$, $\mathrm{CD} 4^{+}$Foxp $3^{+} \mathrm{CD} 127^{\text {Low/- }}$ protocol) and acute (flu-like: using any protocol) viral infections, the percentage of Treg on PBMC was increased compared with controls $(p<0.05)$ (Fig. 2A). However, when the Treg were defined as $\mathrm{CD} 4^{+} \mathrm{CD} 25^{+} \mathrm{CD} 127^{\mathrm{Low} /-}$ in HIV, but not in flu-like infected patients, the percentage was similar to that healthy controls, indicating that this protocol is not suitable to define Treg in HIV patients.

Similarly, and related to these differences, absolute counts of Treg were not significantly different in PBMC from healthy controls and flu-like patients (intragroup comparisons) in any of the protocols used (data not shown), but varied in HIV-infected patients; in the HIV-U group the Treg counts were 202 cells/ $\mu 1(142-243$ cells $/ \mu l)$ and 163 cells $/ \mu 1$ (116-235 cells $/ \mu 1)$ when the Treg were defined as $\mathrm{CD} 4^{+}{ }^{+}$oxp $^{+}$, and $\mathrm{CD}^{+}{ }^{+} \mathrm{Foxp} 3^{+} \mathrm{CD} 127^{\text {Low/- }}$ respectively; however, the counts were significantly lower, only 117 cells $/ \mu \mathrm{l}(96-178 \mathrm{cells} / \mu \mathrm{l})$, when these cells were defined as $\mathrm{CD} 4^{+} \mathrm{CD} 25^{+} \mathrm{CD} 127^{\text {Low/ }}$ (Fig. $2 \mathrm{~B} ; \mathrm{p}<0.01$ compared to $\mathrm{CD} 4^{+} \mathrm{Foxp}^{+}$). Similarly, in the HIV-VL group the count of Treg defined as $\mathrm{CD} 4^{+} \mathrm{CD} 25^{+} \mathrm{CD} 127^{\text {Low/- }}$ was significantly lower than $\mathrm{CD}^{+}{ }^{+} \mathrm{Foxp}^{+}{ }^{+}(107 \mathrm{cells} / \mu 1(58-187 \mathrm{cells} / \mu \mathrm{l})$ vs $(173 \quad$ cells $/ \mu 1 \quad(108-360 \quad$ cells $/ \mu 1) ; \quad \mathrm{p}<0.001) \quad$ and

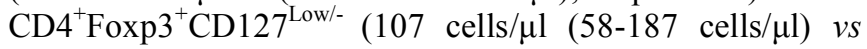
(179 cells/ $\mu$ l (104-269 cells $/ \mu \mathrm{l}) ; \mathrm{p}<0.01)$ (Fig. 2B). In PBMC, HIV patients exhibited the highest Treg counts $\left(\right.$ Foxp $\left.^{+}\right)$, compared to controls (HIV-U: 202 cells/ $\mu 1$ vs HC: 101 cells $/ \mu \mathrm{l}$; and HIV-VL: 173 cells $/ \mu 1$ vs HC: 101 cells $/ \mu$; both $\mathrm{p}<0.05$ ).

GALT is the primary site of damage during HIV infection, where the virus induces many quantitative and functional changes in the Tcon subset [22]. Therefore, we also analyzed biopsy samples of this tissue. When the frequency of Treg was evaluated in GALT samples from HIV patients, the differences, depending on the protocol used, were more evident. In both groups of HIV-infected individuals the Treg percentage in GALT were similar when the Treg were defined as $\mathrm{CD}^{+} \mathrm{Foxp}^{+}$, and $\mathrm{CD} 4^{+} \mathrm{Foxp}^{+}$ $\mathrm{CD} 127^{\mathrm{Low} /}$; however, when these cells were defined as $\mathrm{CD} 4^{+} \mathrm{CD} 25^{+} \mathrm{CD} 127^{\text {Low/ }}$, a significant decrease in the frequency were observed compared to $\mathrm{CD} 4^{+} \mathrm{Foxp} 3^{+}$(HIV-U: $8 \%(5-15 \%)$ vs $14 \%(12-16 \%)$ or HIV-VL: $12 \%$ (7-14\%) vs $18 \%(16-27 \%) ; \mathrm{p}<0.001)$ (Fig. 2C). Again, in healthy controls the percentage of Treg in GALT was similar independent of the protocol used (Fig. 2C, upper panel), and the Treg frequency was significantly lower compared to HIV patients, using $\mathrm{CD}^{+} \mathrm{Foxp}^{+} \mathrm{CD} 127^{\text {Low/- }}$ or $\mathrm{CD}^{+} \mathrm{Foxp}^{+}$ protocols (both, $\mathrm{p}<0.001$ ). No differences were observed using the $\mathrm{CD} 4^{+} \mathrm{CD} 25^{+} \mathrm{CD} 127^{\mathrm{Low} /-}$ protocol. The Treg frequency in GALT was not measured in flu-like patients.

The comparison between tissues showed that the Treg frequency increases in GALT compared to peripheral blood in all 3 groups tested: controls, HIV-U and HIV-VL; the increase was $\sim 1.7, \sim 2, \sim 2.4$ times, respectively, when the protocols $\mathrm{CD}^{+}{ }^{+} \mathrm{Foxp}^{+} \quad(\mathrm{p}=0.001)$ and $\mathrm{CD}^{+}{ }^{+} \mathrm{Foxp}^{+}$ $\mathrm{CD} 127^{\text {Low/ }}(\mathrm{p}=0.003)$ were used. Treg identification with the protocols $\mathrm{CD}^{+} \mathrm{Foxp}^{+}$and $\mathrm{CD}^{+} \mathrm{Foxp}^{+} \mathrm{CD} 127^{\mathrm{Low} /-}$ in PBMC $(\mathrm{r}=0.80, \mathrm{p}=0.0001)$ and GALT $(\mathrm{r}=0.82, \mathrm{p}=0.0001)$ from HIV patients exhibit the highest positive correlation (Fig. 3A, B), indicating that both protocols are suitable to determine Treg frequency in these samples.

HIV-1 Infected Patients Exhibit Alteration in the Expression of $\mathrm{CD} 25$ Molecule in $\mathrm{CD4}^{+} \mathrm{Foxp3}^{+} \mathrm{T}$ Cells in Peripheral Blood and Rectal Tissue

To evaluate potential variations in the Treg phenotype, the expression of CD25 was analyzed in the Foxp3 $\mathrm{CD} 4^{+}$ gate. We measured the percentage of cells expressing this molecule and the mean MFI of its expression (Fig. 1B). As shown in Fig. (4A), the percentages of $\mathrm{CD} 25^{+}$Treg cells are lower in HIV patients compared with healthy controls and flu-like patients. In the HIV-U, the percentages of CD25 cells were $42 \%(35-58 \%)$ and $33 \%(27-47 \%)$ in PBMC and GALT respectively; in HIV-VL these percentages correspond to $39 \%(25-40 \%)$ in PBMC and $35 \%(26-49 \%)$ in GALT, compared to $56 \%(51-64 \%)$ and $47 \%(35-53 \%)$ in PBMC and GALT, respectively, in cells from controls. In fact, the percentage of $\mathrm{CD} 25^{+}$Treg from HIV patients (with or undetectable VL) was about $\sim 1.4$-fold lower than from controls in both PBMC and GALT ( $<0.05$ ) (Fig. 4A, lower panel). The percentage of $\mathrm{CD} 25^{+}$Treg in PBMC from flulike patients was 58\% (51-60\%), similar to controls (Fig. 4A, middle panel). Analyzes of CD25 in Tcon (CD4 ${ }^{+}$Foxp3-) showed that the percentage of $\mathrm{CD} 25^{+}$in PBMC and GALT increases in cells from HIV patients (data not shown), suggesting that the low expression of $\mathrm{CD} 25^{+}$occurs only in the Treg subset.

$\mathrm{CD}^{+}{ }^{+}$Treg from HIV-1 Patients with Detectable Viral Load and Flu-Like Infected Individuals Exhibit Higher Density of the CD25 Molecule

We then examined whether the reduction of the CD25 molecule in Foxp $3^{+} \mathrm{CD}^{+}$cells from HIV patients affects not only the percentage of cells expressing this molecule but also the density of its expression per cell. As shown in Fig. (4B), the CD25 MFI in Treg from control samples was 17 (13-20) and 11 (8-16), in PBMC and GALT, respectively; in HIV-U 


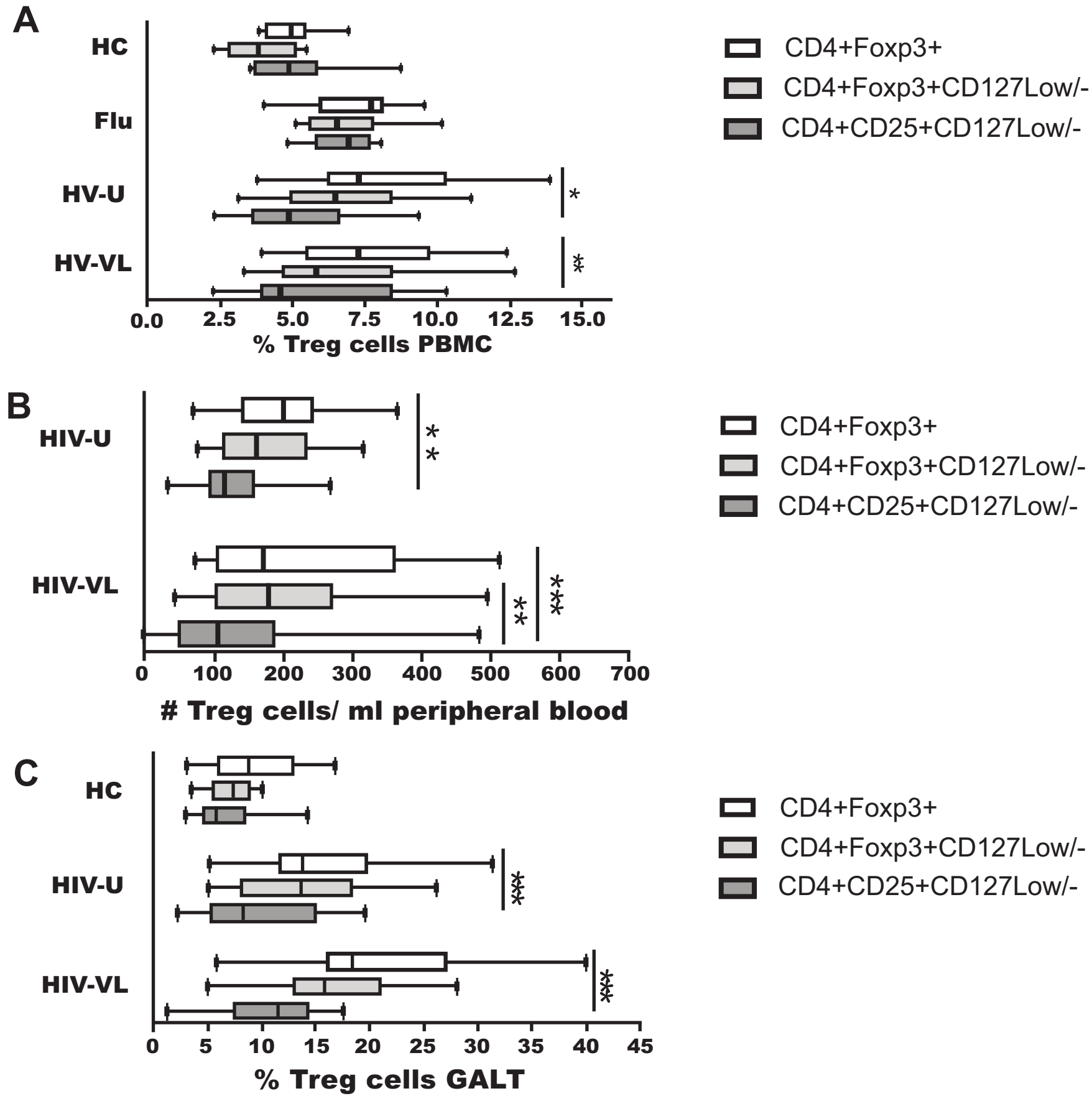

Fig. (2). Frequency of Treg $\mathrm{CD}^{+} \mathrm{Foxp3}^{+}, \mathrm{CD}^{+} \mathrm{Foxp3}^{+} \mathrm{CD} 127^{\mathrm{Low} /-}$ and $\mathrm{CD}^{+} \mathrm{CD}^{+} 5^{+} \mathrm{CD} 127^{\mathrm{Low} /-}$ in samples from healthy controls, individuals with acute flu-like symtoms, chronically HIV-infected with or undetectable viral load. Whisker box figures show phenotypic characterization of Treg. A) Percentage of Treg from PBMC of healthy controls ( $\mathrm{n}=13$ ) (upper panel), flu-like symptoms patients $(\mathrm{n}=9)$ (middle panel), HIV-U ( $\mathrm{n}=13)$ (middle panel) and HIV-VL ( $\mathrm{n}=19)$ (lower panel). B) Treg absolute count in PBMC samples from HIVU and HIV-VL patients. C) Percentage of Treg from GALT of healthy controls (upper panel), HIV-U (middle panel) and HIV-VL ( $\mathrm{n}=10$ ) (lower panel). Median and 25-75 interquartiles ranges are represented. Intra groups were compared by the Friedmann test and Dunn's multiple post-test. Significant differences are indicated by $* \mathrm{p}<0.05, * * \mathrm{p}<0.01, * * * \mathrm{p}<0001$.

the CD25 MFI was 35 (18-60) and 15 (9-57). Although in these patients the range was very wide, no significant differences were found in HIV-U vs HC.

In contrast, patients with acute flu-like or HIV chronic infection with detectable viral load exhibits the highest levels of CD25 MFI, compared with controls. In flu-like samples, the CD25 MFI was 75 (64-88) in PBMC; it was 87 (51-97) and 62 (16-76) in HIV-VL samples from PBMC and GALT, respectively (Fig. 4B). These results suggest that viral replication could modify the density of the expression of CD25 molecule on Treg. To evaluate the strength of the association between the Treg phenotype and viral load, 
A

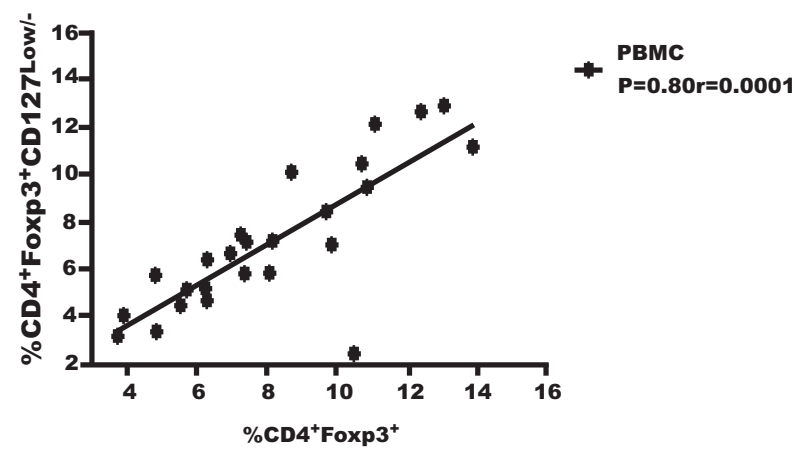

B

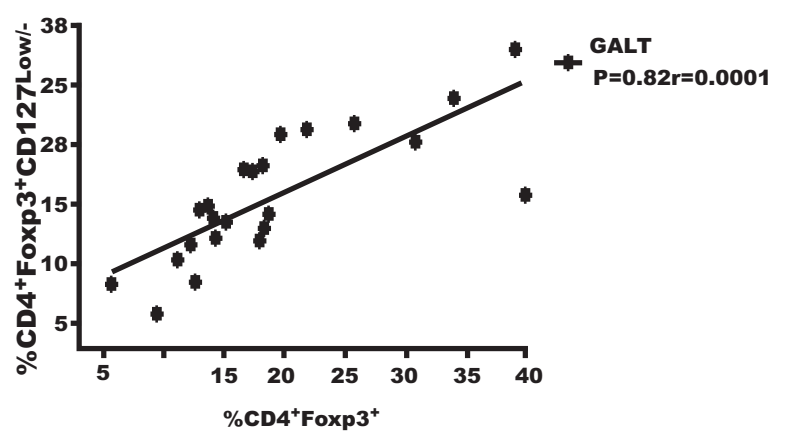

Fig. (3). Correlations between the different protocols to characterize the Treg cells in samples from PBMC and GALT. Spearman correlations between Treg frequency charactized by $\mathrm{CD} 4^{+} \mathrm{Foxp} 3^{+}$and $\mathrm{CD} 4^{+} \mathrm{Foxp} 3^{+} \mathrm{CD} 127^{\mathrm{Low} /-}$ in A) PBMC. B) and GALT.

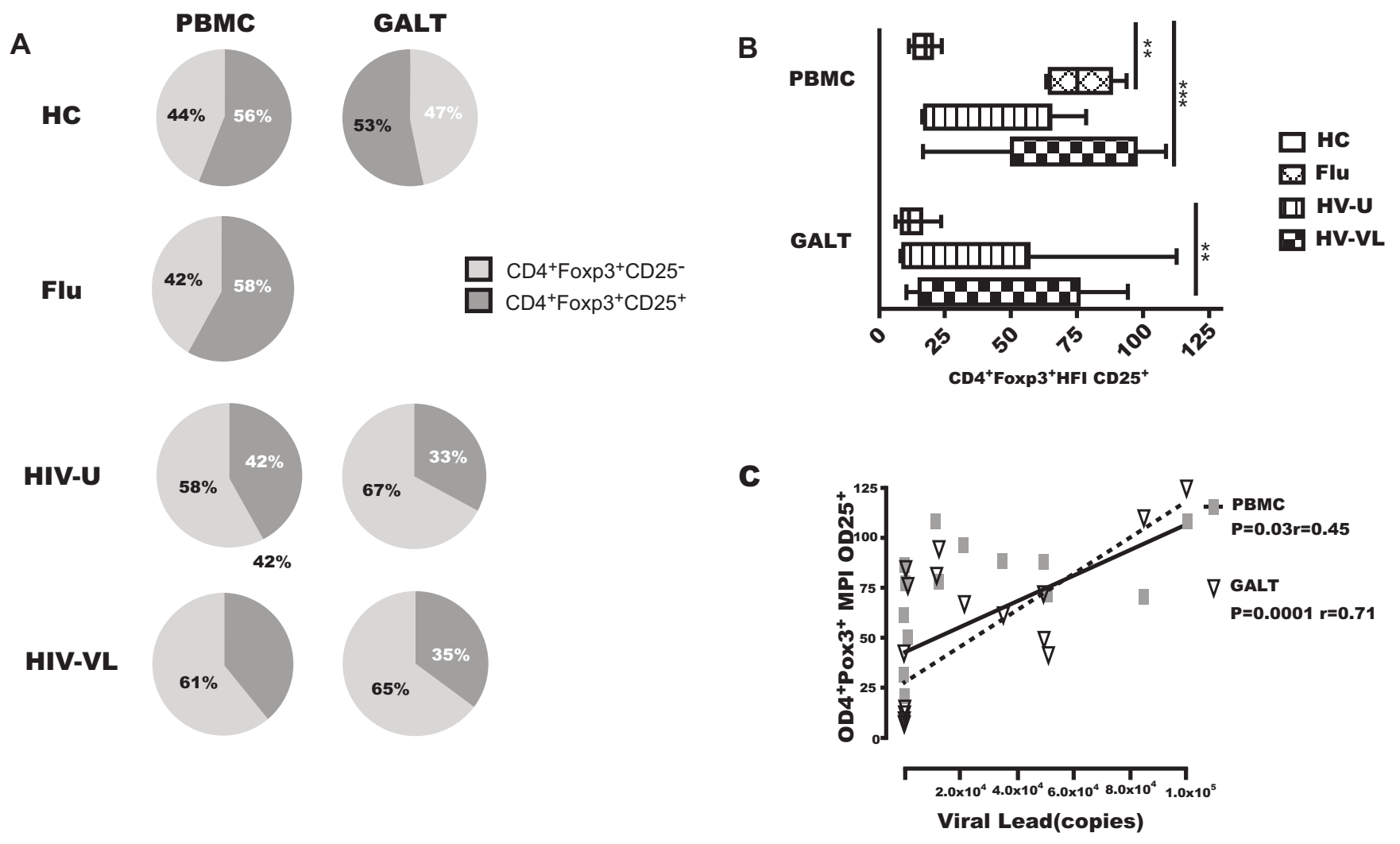

Fig. (4). Percentage and MFI of CD25 molecule of Treg in samples from healthy controls, chronically HIV-infected and individuals with acute flu-like symptoms. A) Pie charts show the percentage of Treg (CD $4^{+}$Foxp $3^{+}$) expressing the CD25 (CD $4^{+}$Foxp $\left.3^{+} \mathrm{CD} 25^{+}\right)$or negative for the CD25 molecule (CD4 ${ }^{+}$Foxp $\left.^{+}{ }^{+} \mathrm{CD} 25^{\circ}\right)$ in PBMC and GALT samples from controls $(\mathrm{n}=10)$, HIV-U ( $\left.\mathrm{n}=13\right)$; HIV-VL ( $\left.\mathrm{n}=19\right)$, and in PBMC from flu-like patients $(\mathrm{n}=9)$. B) Whisker box figures show MFI of CD25 in Treg (in the gate of $\mathrm{CD} 4^{+} \mathrm{Foxp} 3^{+} \mathrm{CD} 25^{+}$) in $\mathrm{PBMC}$ and GALT samples; median and interquartile ranges are represented. C) MFI of CD25 of Treg in PBMC and GALT were positively correlated with HIV viral load. Groups were compared by the Kruskal Wallis test and Dunn's multiple comparisons post-test. Significant differences are indicated by $* * \mathrm{p}<0.01, * * * \mathrm{p}<0001$.

correlations were examined in $\mathrm{HIV}+$ patients. Interestingly, the CD25 MFI in Treg from PBMC and GALT was positively correlated with viral replication (PBMC $\mathrm{r}=0.45$, $\mathrm{p}=0.03$; GALT r=0.71, $\mathrm{p}=<0.0001)$ (Fig. 4C).

Finally, we analyzed whether the changes on the CD25 expression on Treg was due to an alteration in the expression of the transcription factor Foxp3 (Fig. 1C); the MFI of Foxp3 was similar among Treg from controls, flu and HIV patients on both tissues (PBMC; $p=0.635$ and GALT; $p=0.802$ ), ruling out this possibility (Fig. 5).

In conclusion, these results indicate that Treg from chronic HIV infected patients exhibit an alteration in the expression of the CD25 molecule, resulting in a reduced percentage of $\mathrm{CD}_{2} 5^{+}$cells. This finding suggests that detection of Treg based only in the expression of the CD25 molecule, could result in an underestimation of the 
frequency of this cell subset in HIV infected individuals. On the other hand, the higher intensity of CD25 expression per cell within the positive cell subpopulation could be associated with the chronic state of hyperactivation during HIV infection.

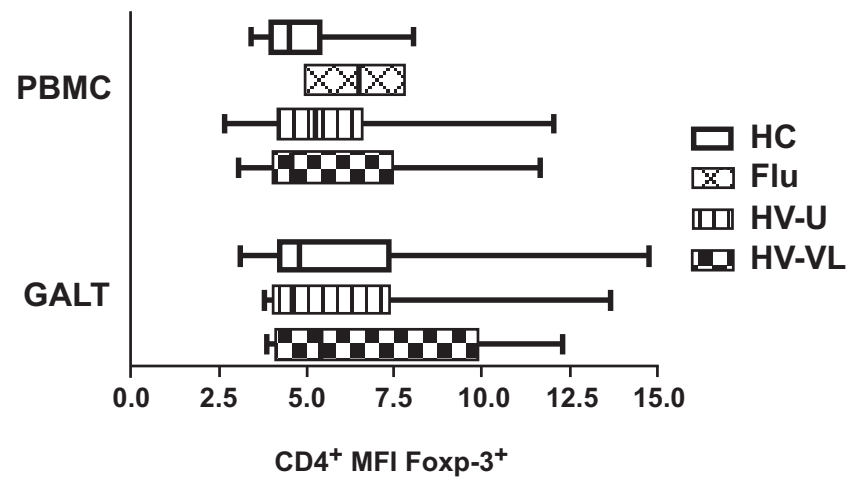

Fig. (5). MFI of the transcription factor Foxp3 on samples from healthy controls, chronically HIV-infected and individuals with acute flu-like symtoms. Whisker box figures show MFI of Foxp3 in Treg in PBMC and GALT samples from controls $(n=10)$ and HIV patients (HIV-U $n=13$; HIV-VL $n=19$ ), and in PBMC from flu-like patients $(n=9)$. Groups were compared by the Kruskal Wallis test and Dunn's multiple comparisons post-test.

\section{DISCUSSION}

Since the description of Treg, their phenotypic characterization has been complex; in the beginning, high expression of CD25 in the $\mathrm{CD} 4^{+} \mathrm{T}$ cell subset was widely used to characterize them. Unfortunately, the ability to accurately gate for CD25 is rather arbitrary and the expression of this molecule is not specific to Treg. Several studies demonstrated that low or negative CD127 expression is an excellent biomarker of Treg, particularly in combination with CD25 or Foxp3. In fact, CD127 and CD25 stain allows human Treg enrichment for in vitro functional studies [23, 24]. So far, the combination of CD25, CD127 and Foxp3 expression is considered the best way to distinguish between human Treg and $\mathrm{CD}^{+}$Tcon [23]. According to previous studies, similar percentages of Treg were reported when these cells were defined with the combination of these molecules $\left(\mathrm{CD} 25^{+} \mathrm{Foxp}^{+}\right.$; $\mathrm{CD} 25^{+} \mathrm{CD} 127^{\text {Low/ }}$, Foxp $3^{+} \mathrm{CD} 127^{\text {Low }}$ ) in basal conditions in PBMC and lymphoid nodes from adults, children and cord blood from neonates, without infection or metabolic diseases [16].

In addition, the characterization of Treg in patients with viral respiratory acute infections is largely unknown. During the first week of influenza H1N1 $[25,26]$ and influenza A [27] infection an increase in the frequency of Treg in PBMC were reported. In agreement with these results, we also observed high frequency of Treg in patients with flu-like symptoms compared to uninfected controls. No differences were observed in the protocol used to identify these cells. Unfortunately, we could not obtain respiratory tract samples from the flu-like patients to compare with PBMC.

In contrast to controls and patients with flu-like illness, in this study the analysis of Treg in chronic HIV infected individuals shows that the frequency of this cell subpopulation varies depending on the protocol used; in particular, the detection of $\mathrm{CD} 25^{+} \mathrm{CD} 127^{\text {Low/- }}$ cells produced a lower frequency of Treg compared to the protocols in which the detection of Foxp3 was included. In this respect, Bi et al., 2009 described that gating $\mathrm{CD} 4^{+} \mathrm{CD} 25^{+/ \text {hi }} \mathrm{CD} 127^{\text {Low }}$ was difficult to analyze because staining showed a smear of both CD25 and CD127 and proposed that gaiting Foxp3 in CD4 cells gave a clearer staining [28]. In accordance to this previous report, our results also indicate that the identification of Treg cells in samples from HIV patients should rely in the detection of the marked Foxp3 alone or in combination with $\mathrm{CD} 127$; in fact, these two protocols showed the highest correlation in both types of samples. Although the CD25 molecule is a key phenotypic and functional marker of Treg, the detection of this cell subset based on its expression might result in underestimation of these cells.

In accordance with our results, Ndhlovu et al., 2008 reported a similar frequency of Treg, defined as $\mathrm{CD} 25^{+}$ $\mathrm{CD} 127^{\text {Low/ }}$ cells in PBMC in HIV patients, with both primary and chronic infection, and controls; however, when these authors characterized these cells as $\mathrm{Foxp} 3^{+} \mathrm{CD} 127^{\mathrm{Low} /}$, the patients exhibited an increase of this subset compared to controls [10]. In this report, the authors hypothesized that HIV patients contain different sub-subsets of Treg with different phenotypes and functions. Also, Pozo-Balado et al., 2010 reported that the $\mathrm{CD} 4^{+} \mathrm{CD} 25^{+/ h i} \mathrm{CD} 127^{\text {Low }}$ phenotype does not accurately identify Treg in PBMC from viremic patients [29]. However, in this report the comparison did not include healthy controls or Foxp $3^{+}$, Foxp $3^{+} \mathrm{CD} 127^{\text {Low/ }}$ analysis. In samples from GALT, epple et al., 2006 [5] and Shaw et al., 2011 demonstrated that the frequency of Treg was consistently higher in HIV patients with high viral loads compared to seronegatives [30]. However, in peripheral blood, the detection of Treg with the $\mathrm{CD} 25^{+} \mathrm{CD} 127^{\text {lo }}$ protocol indicated a lower frequency of these cells in HIV patients with undetectable viral load (controllers) compared to uninfected individuals [30]. Together, these data are in agreement with the fact that Treg increase during HIV infection and their characterization changes depending on how these cells are analyzed, indicating that classic strategies to detect Treg cells might be suitable, but carefully considered, depending on the type of viral infection.

The results of the present study suggest that there is an expansion/accumulation of Treg during HIV infection in both peripheral blood and GALT tissue; the expanded cells exhibit an altered expression of the CD25 molecule. Indeed, it was previously shown that the percentage of Treg in PBMC expressing the CD25 molecule (Foxp $3^{+} \mathrm{CD} 25^{+}$) is about $45 \%$ in controls and $34 \%$ in HIV patients [31]. Interestingly, the majority of evidence indicating the low frequency of CD25 in Treg is reported particularly in tissue samples $[5,32,33]$. In fact, using immunohistochemistry and immunofluorescence analyses in samples from lamina propia, lower CD25 expression in Foxp $3^{+}$cells has been reported [5]. Confocal micrographs from tonsillar biopsies have shown Foxp $3^{+} \mathrm{CD} 25^{+}$percentages of $19 \%, 44 \%$, and $75 \%$ in HIV progressors, non progressors, and uninfected donors, respectively [33]. Other reports on tonsillar biopsies detected only a $19 \%$ and $16 \%$ of Foxp $3^{+} \mathrm{CD} 25^{+}$cells in HIVuntreated and treated patients, respectively [32]. Analysis of $\mathrm{CD} 25^{+}$and $\mathrm{CD} 25^{-} \mathrm{CD} 4^{+} \mathrm{T}$ cells from in spleens and lymph 
nodes of SIV-infected macaques, confirm that the population of Foxp3 expressing cells in lymphoid tissues is not limited to a CD $25^{+}$phenotype and that $\mathrm{CD} 25^{-}$Foxp $^{+}$may be present in lymphoid tissues during chronic infection [34]. Unfortunately, comparisons in the frequency of Treg using different phenotypic markers were not performed by these authors. Although previous findings have demonstrated a decrease in the expression of CD25, this article along with the recently published by Shaw et al., [30] are the only ones that include a comparison of different current protocols for identifying Treg cells in peripheral blood and GALT samples in HIV infected patients.

In the present study we report that significant changes in the CD25 expression occur in Treg from HIV patients in both at the percentange of cells expressing this molecule and at the density of expression, measured in terms of MFI. Experimental evidence suggest several possibilities to account for this observation: (i) chronic expansion of Treg in vivo results in low levels of CD25 expression, retaining their suppressive activity, as previously reported in a murine model [35]; this constant expansion (high Treg frequency) is observed also in GALT from HIV infected patients [5, 30]; (ii) it might reflect internalization of the CD25 molecule after IL-2 binding [36]; in fact, the expansion of $\mathrm{CD} 4{ }^{+} \mathrm{CD} 25^{10} \mathrm{CD} 127^{\mathrm{lo}}$ Foxp3 ${ }^{+}$Treg is one of the long-term effects of IL-2 therapy in HIV patients [37, 38]; (iii) in vitro assays have shown that HIV induces down regulation of the CD25 molecule in $\mathrm{CD}^{+}$infected cells [39]. In addition, HIV viral proteins are involved in this process, inhibiting IL-2R expression; HIV p29 protein induces a two fold increase in the intracellular cyclic adenosine 3',5'-monophosphate (cAMP) in PBMC which is associated with the decrease of CD25 [40]. HIV Tat protein and the Gp120 also decrease the expression of this molecule in Jurkat cells line [41] and CD $4{ }^{+} \mathrm{T}$ cells [42], respectively.

On the other hand, it is important to note that CD25 expression per cell in Treg from HIV-untreated and flu-like patients increases compared to controls despite similar levels of Foxp3 expression, suggesting a competitive advantage for IL-2, reducing the available levels of this cytokine in the microenvironment [43]. The increase of CD25 MFI can be explained as a consequence of cellular activation; $\mathrm{CD}^{+} \mathrm{T}$ cells exposed to HIV upregulated the expression of CD25, in Tcon $\left(\mathrm{CD}^{+} \mathrm{CD}^{-} 5^{-}\right.$[44] and in Treg $\left(\mathrm{CD} 4^{+} \mathrm{CD} 25^{+}\right)$cells [33], along with the expression of other activation molecules such as HLA-DR [45, 46]. In fact, there was a positive correlation between the CD25 MFI and the viral load, supporting that HIV induces activation of $\mathrm{CD}^{+}$and Treg cells as previously reported [46, 47]. Interestingly, the MFI of CD25 in HIV-U was lower compared to HIV-VL patients, supporting the idea that cellular activation is partially controlled by antiretroviral treatment [48].

In conclusion, here we report an additional phenotypic alteration of Treg from HIV patients. The percentage of Treg expressing CD25 decreases, making the detection of this molecule an unsuitable tool to characterize Treg in HIV patients, particularly in tissue samples. The data presented here also suggest that the use of flow sorting and magnetic columns to deplete Treg based on the expression of CD25 $[49,50]$ does not ensure complete elimination of this cell population, which may affect functional assays. Although we are aware that the sample size was limited, and the results required further verification, these results point to the urgent requirement to develop additional methods to deplete Treg from PBMC, as a way to measure the role of this cell subpopulation in the context of chronic infections, in particular HIV.

\section{ACKNOWLEDGEMENTS}

The authors acknowledge the patients and volunteers who kindly participated in this study. We also thank the health personnel from the Clinical Bolivariana Medellin. Funding: CMR is recipient of a doctoral scholarship and the study was supported by Colciencias, grant 111540820490-1 and "Programa Sostenibilidad 2011-2012, UdeA. We thank Anne-Lise Haenni for all her constructive comments.

\section{COMPETING INTERESTS}

The authors have no conflicts of interest.

\section{ETHICAL APPROVAL}

This study was approved by the Ethics Committee of the Faculty of Medicine, University of Antioquia, Medellin, Colombia.

$$
\begin{aligned}
& \text { ABBREVIATIONS } \\
& \text { PBMC }=\text { Peripheral blood mononuclear cells } \\
& \text { GALT }=\text { Gut associated lymphoid tissue } \\
& \text { RC } \quad=\text { Rectal cells } \\
& \text { Tregs } \quad=\text { Regulatory T cells } \\
& \text { Tcon } \quad=\text { Conventional T cells } \\
& \text { HC } \quad=\text { Healthy controls } \\
& \text { HIV } \quad=\text { Human immunodeficiency virus } \\
& \text { FLU } \quad=\text { Individuals with acute flu-like symptoms } \\
& \text { HAART }=\text { Highly active antiretroviral therapy } \\
& \text { VL } \quad=\text { Viral load } \\
& \text { FCS } \quad=\text { Fetal calf serum } \\
& \text { DPBS }=\text { Dulbeco's phosphate buffered saline } \\
& \text { MFI } \quad=\text { Mean fluorescence intensity. } \\
& \text { REFERENCES }
\end{aligned}
$$

\section{REFERENCES}

[1] Belkaid Y. Regulatory T cells and infection: a dangerous necessity. Nat Rev Immunol 2007; 7: 875-88.

[2] Fehervari Z, Sakaguchi S. CD4+ Tregs and immune control. J Clin Invest 2004; 114: 1209-17.

[3] Sachdeva M, Fischl MA, Pahwa R, Sachdeva N, Pahwa S. Immune exhaustion occurs concomitantly with immune activation and decrease in regulatory $\mathrm{T}$ cells in viremic chronically HIV-1infected patients. J Acquir Immune Defic Syndr 2010; 54: 447-54.

[4] Chase AJ, Yang HC, Zhang H, Blankson JN, Siliciano RF Preservation of FoxP3+ regulatory $\mathrm{T}$ cells in the peripheral blood of human immunodeficiency virus type 1-infected elite suppressors correlates with low CD4+ T-cell activation. J Virol 2008; 82: 830715.

[5] Epple HJ, Loddenkemper C, Kunkel D, et al. Mucosal but not peripheral FOXP3+ regulatory $\mathrm{T}$ cells are highly increased in untreated HIV infection and normalize after suppressive HAART. Blood 2006; 108: 3072-8.

[6] Cao W, Jamieson BD, Hultin LE, Hultin PM, Detels R. Regulatory $\mathrm{T}$ cell expansion and immune activation during untreated HIV type 
1 infection are associated with disease progression. AIDS Res Hum Retroviruses 2009; 25: 183-91.

[7] Schulze Zur Wiesch J, Thomssen A, Hartjen P, et al. Comprehensive analysis of frequency and phenotype of $\mathrm{T}$ regulatory cells in HIV infection: CD39 expression of FoxP3+ T regulatory cells correlates with progressive disease. J Virol 2011; 85: 1287-97.

[8] Suchard MS, Mayne E, Green VA, et al. FOXP3 expression is upregulated in CD4T cells in progressive HIV-1 infection and is a marker of disease severity. PLoS One 2010; 5: e11762.

[9] Hunt PW, Landay AL, Sinclair E, et al. A low T regulatory cell response may contribute to both viral control and generalized immune activation in HIV controllers. PLoS One 2011; 6: e15924.

[10] Ndhlovu LC, Loo CP, Spotts G, Nixon DF, Hecht FM. FOXP3 expressing CD127lo CD4+ T cells inversely correlate with CD38+ CD8+ T cell activation levels in primary HIV-1 infection. J Leukoc Biol 2008; 83: 254-62.

[11] Baecher-Allan C, Brown JA, Freeman GJ, Hafler DA. $\mathrm{CD} 4+\mathrm{CD} 25$ high regulatory cells in human peripheral blood. $\mathrm{J}$ Immunol 2001; 167: 1245-53.

[12] Baecher-Allan C, Brown JA, Freeman GJ, Hafler DA. $\mathrm{CD} 4+\mathrm{CD} 25+$ regulatory cells from human peripheral blood express very high levels of CD25 ex vivo. Novartis Found Symp 2003; 252: 67-88; discussion -91: 106-14.

[13] Liu W, Putnam AL, Xu-Yu Z, et al. CD127 expression inversely correlates with FoxP3 and suppressive function of human CD4+ T reg cells. J Exp Med 2006; 203: 1701-11.

[14] Seddiki N, Santner-Nanan B, Tangye SG, et al. Persistence of naive CD45RA+ regulatory T cells in adult life. Blood 2006; 107: 2830-8.

[15] Ziegler SF. FOXP3: of mice and men. Annu Rev Immunol 2006; 24: 209-26.

[16] Seddiki N, Santner-Nanan B, Martinson J, et al. Expression of interleukin (IL)-2 and IL-7 receptors discriminates between human regulatory and activated T cells. J Exp Med 2006; 203: 1693-700.

[17] Roncador G, Brown PJ, Maestre L, et al. Analysis of FOXP3 protein expression in human $\mathrm{CD} 4+\mathrm{CD} 25+$ regulatory $\mathrm{T}$ cells at the single-cell level. Eur J Immunol. 2005; 35: 1681-91.

[18] Sakaguchi S, Sakaguchi N, Asano M, Itoh M, Toda M. Immunologic self-tolerance maintained by activated $\mathrm{T}$ cells expressing IL-2 receptor alpha-chains (CD25). Breakdown of a single mechanism of self-tolerance causes various autoimmune diseases. J Immunol 1995; 155: 1151-64.

[19] Guadalupe M, Reay E, Sankaran S, et al. Severe CD4+ T-cell depletion in gut lymphoid tissue during primary human immunodeficiency virus type 1 infection and substantial delay in restoration following highly active antiretroviral therapy. J Virol 2003; 77: 11708-17.

[20] Shacklett BL, Yang O, Hausner MA, et al. Optimization of methods to assess human mucosal T-cell responses to HIV infection. J Immunol Methods 2003; 279: 17-31.

[21] Presicce P, Moreno-Fernandez ME, Lages CS, Orsborn KI, Chougnet CA. Association of two clones allows for optimal detection of human FOXP3. Cytometry A 2010; 77: 571-9.

[22] Mehandru S, Poles MA, Tenner-Racz K, et al. Primary HIV-1 infection is associated with preferential depletion of $\mathrm{CD} 4+\mathrm{T}$ lymphocytes from effector sites in the gastrointestinal tract. J Exp Med 2004; 200: 761-70.

[23] Hartigan-O'Connor DJ, Poon C, Sinclair E, McCune JM. Human CD4+ regulatory T cells express lower levels of the IL-7 receptor alpha chain (CD127), allowing consistent identification and sorting of live cells. J Immunol Methods 2007; 319: 41-52.

[24] Fazekas de St Groth B, Zhu E, Asad S, Lee L. Flow cytometric detection of human regulatory T cells. Methods Mol Biol 2011; 707: 263-79.

[25] Chen HX, Chen BG, Shi WW, et al. Induction of cell surface human leukocyte antigen-G expression in pandemic H1N1 2009 and seasonal H1N1 influenza virus-infected patients. Hum Immunol 2011; $72: 159-65$.

[26] Guo X, Chen Y, Li X, et al. Dynamic variations in the peripheral blood lymphocyte subgroups of patients with 2009 pandemic H1N1 swine-origin influenza A virus infection. Virol J 2011; 8: 215.

[27] Piersma SJ, van der Hulst JM, Kwappenberg KM, Goedemans R, van der Minne CE, van der Burg SH. Influenza matrix 1-specific human CD4+ FOXP3+ and FOXP3(-) regulatory $\mathrm{T}$ cells can be detected long after viral clearance. Eur J Immunol 2010; 40: 306474.

[28] Bi X, Suzuki Y, Gatanaga H, Oka S. High frequency and proliferation of CD4+ FOXP3+ Treg in HIV-1-infected patients with low CD4 counts. Eur J Immunol 2009; 39: 301-9.

[29] Del Pozo-Balado Mdel M, Leal M, Mendez-Lagares G, Pacheco YM. CD4(+)CD25(+/hi)CD127(lo) phenotype does not accurately identify regulatory $\mathrm{T}$ cells in all populations of HIV-infected persons. J Infect Dis 2010; 201: 331-5.

[30] Shaw JM, Hunt PW, Critchfield JW, et al. Increased frequency of regulatory $\mathrm{T}$ cells accompanies increased immune activation in rectal mucosae of HIV-positive noncontrollers. J Virol 2011; 85: 11422-34.

[31] Rallon NI, Lopez M, Soriano V, et al. Level, phenotype and activation status of $\mathrm{CD} 4+\mathrm{FoxP} 3+$ regulatory $\mathrm{T}$ cells in patients chronically infected with human immunodeficiency virus and/or hepatitis $C$ virus. Clin Exp Immunol 2009; 155: 35-43.

[32] Andersson J, Boasso A, Nilsson J, et al. The prevalence of regulatory $\mathrm{T}$ cells in lymphoid tissue is correlated with viral load in HIV-infected patients. J Immunol 2005; 174: 3143-7.

[33] Nilsson J, Boasso A, Velilla PA, et al. HIV-1-driven regulatory Tcell accumulation in lymphoid tissues is associated with disease progression in HIV/AIDS. Blood 2006; 108: 3808-17.

[34] Boasso A, Vaccari M, Hryniewicz A, et al. Regulatory T-cell markers, indoleamine 2,3-dioxygenase, and virus levels in spleen and gut during progressive simian immunodeficiency virus infection. J Virol 2007; 81: 11593-603.

[35] Nishimura E, Sakihama T, Setoguchi R, Tanaka K, Sakaguchi S. Induction of antigen-specific immunologic tolerance by in vivo and in vitro antigen-specific expansion of naturally arising Foxp3+CD25+CD4+ regulatory $\mathrm{T}$ cells. Int Immunol 2004; 16: 1189-201.

[36] Fulton RB, Meyerholz DK, Varga SM. Foxp3+CD4 regulatory T cells limit pulmonary immunopathology by modulatin the CD8 T cell response during sincytial virus infection. J Immunol 2010; 185: 2382-292.

[37] Velilla PA, Shata MT, Lages CS, Ying J, Fichtenbaum CJ, Chougnet C. Effect of low-dose IL-2 immunotherapy on frequency and phenotype of regulatory $\mathrm{T}$ cells and NK cells in HIV/HCVcoinfected patients. AIDS Res Hum Retroviruses 2008; 24: 52-61.

[38] Weiss L, Letimier FA, Carriere M, et al. In vivo expansion of naive and activated $\mathrm{CD} 4+\mathrm{CD} 25+\mathrm{FOXP} 3+$ regulatory $\mathrm{T}$ cell populations in interleukin-2-treated HIV patients. Proc Natl Acad Sci USA 2010; 107: 10632-7.

[39] Locher CP, Witt SA, Kassel R, Dowell NL, Fujimura S, Levy JA. Differential effects of R5 and X4 human immunodeficiency virus type 1 infection on CD4+ cell proliferation and activation. J Gen Virol 2005; 86: 1171-9.

[40] Ammar A, Sahraoui Y, Tsapis A, Bertoli AM, Jasmin C, Georgoulias V. Human immunodeficiency virus-infected adherent cell-derived inhibitory factor (p29) inhibits normal $\mathrm{T}$ cell proliferation through decreased expression of high affinity interleukin-2 receptors and production of interleukin-2. J Clin Invest 1992; 90: 8-14.

[41] Purvis SF, Georges DL, Williams TM, Lederman MM. Suppression of interleukin-2 and interleukin-2 receptor expression in Jurkat cells stably expressing the human immunodeficiency virus Tat protein. Cell Immunol 1992; 144: 32-42.

[42] Bani L, David D, Février M, et al. Interleukin-2 receptor beta and gamma chain dysregulation during the inhibition of CD4 T cell activation by human immunodeficiency virus-1 gp120. Eur J Immunol 1997; 27: 2188-94.

[43] Barthlott T, Moncrieffe H, Veldhoen M, et al. CD25+ CD4+ T cells compete with naive CD4+ T cells for IL-2 and exploit it for the induction of IL-10 production. Int Immunol 2005; 17: 279-88.

[44] Ji J, Cloyd MW. HIV-1 binding to CD4 on CD4+CD25+ regulatory $\mathrm{T}$ cells enhances their suppressive function and induces them to home to, and accumulate in, peripheral and mucosal lymphoid tissues: an additional mechanism of immunosuppression. Int Immunol 2009; 21: 283-94.

[45] Mahalingam M, Peakman M, Davies ET, Pozniak A, McManus TJ, Vergani D. T cell activation and disease severity in HIV infection. Clin Exp Immunol 1993; 93: 337-43.

[46] Biancotto A, Iglehart SJ, Vanpouille C, et al. HIV-1 induced activation of CD4+ $\mathrm{T}$ cells creates new targets for HIV-1 infection in human lymphoid tissue ex vivo. Blood 2008; 111: 699-704. 
[47] Xiao J, Qian KL, Cao QH, et al. HLA-DR expression on regulatory $\mathrm{T}$ cells is closely associated with the global immune activation in HIV-1 infected subjects naïve to antiretroviral therapy. Chin Med J (Engl) 2011; $124: 2340-6$.

[48] Rueda CM, Velilla PA, Chougnet CA, Montoya CJ, Rugeles MT. HIV-induced T-cell activation/ exhaustion in rectal mucosa is controlled only partially by antiretroviral treatment. PLoS One 2012; 7: e30307.
[49] Wichlan DG, Roddam PL, Eldridge P, Handgretinger R, Riberdy JM. Efficient and reproducible large-scale isolation of human CD4+ CD25+ regulatory $\mathrm{T}$ cells with potent suppressor activity. J Immunol Methods 2006; 315: 27-36.

[50] Bresatz S, Sadlon T, Millard D, Zola H, Barry SC. Isolation, propagation and characterization of cord blood derived $\mathrm{CD} 4+$ CD25+ regulatory T cells. J Immunol Methods 2007; 327: 53-62.

(C) Rios et al.; Licensee Bentham Open.

This is an open access article licensed under the terms of the Creative Commons Attribution Non-Commercial License (http: //creativecommons.org/licenses/by$\mathrm{nc} / 3.0 /$ ) which permits unrestricted, non-commercial use, distribution and reproduction in any medium, provided the work is properly cited. 